\title{
Humanização: Cuidado com a Finitude e o Morrer
}

\author{
Barroco, Maria de Fatima Candido; Ferraz, Dayse M. de Melo Coelho; Oliveira, \\ Maridite C. Gomes de; Oliveira, Marli Goulart T.; Muller, Walter \\ Hospital Geral de Sao Mateus - mfatimabarroco@ig.com.br
}

Introdução: a dificuldade dos profissionais da saúde em lidar com o processo da morte e do morrer ao abordar essa etapa da vida na assistência hospitalar, a demanda de acolhimento ao cliente e seus familiares nesse momento, levaram a instituição de saúde a desenvolver um projeto que respondesse a essas necessidades. Objetivo: Desenvolver um conjunto de ações que dessem suporte aos profissionais de saúde para lidar com o processo da morte e do morrer nessa etapa da vida para o acolhimento aos familiares. Método: Criação de Grupo de Trabalho (GT) multidisciplinar, com formação no tema, realização de pesquisa aplicada aos funcionários da instituição, para avaliar dificuldades para lidar com o problema, promoção de palestras e oficinas de sensibilização, capacitação com o Curso RIME (Relaxamento, Imaginação criativa e Espiritualidade) técnica para lidar com pacientes em terminalidade. Resultados: Desde o início os atendimentos, que eram realizados em duplas, tiveram os resultados mais que satisfatórios. de um lado os pacientes que, apesar do momento doloroso, manifestavam primeiro a surpresa pelo apoio que recebiam e explicitamente agradeciam e tornavam-se mais seguros na forma de enfrentamento de sua dor. de outro lado, os profissionais também passaram a buscar o apoio do grupo, antes mesmo de dar a notícia que mais tinham dificuldade. a instituição vem desenvolvendo este projeto há cinco anos, tendo realizado, aproximadamente, 215 acolhimentos entre assistência aos familiares e aos pacientes, e elaborou um protocolo para esse atendimento, que pode ser solicitado pelos profissionais das várias clínicas para assistência pré ou pós finitude, e orientação à família e/ou aplicação da técnica RIME. o grupo mantêm reunião mensal com os participantes atuantes para trocas de experiências, suporte emocional, estudos de casos e para realização de cursos visando a formação de novos integrantes. Conclusões: a experiência mostra que esta iniciativa inovadora é bem recebida tanto por profissionais técnicos e administrativos como pelas pessoas acolhidas. Pudemos perceber a importância dessas ações através de posturas profissionais mais humanas e compreensivas nos momentos difíceis de comunicação seja com os pacientes, seja com os familiares ou os profissionais que têm buscado apoio do grupo para lhes dar suporte, orientação e continência para suas necessidades. Também observamos que os familiares sentem-se apoiados e conseguem elaborar suas perdas de maneira menos desestabilizadora. Esta iniciativa tem promovido um melhor entendimento do processo de vida/morte, possibilitando uma assistência humanizada e respeitosa àqueles que vivenciam este momento doloroso da vida em sua trajetória. "Na verdade, para morrer não é necessária nenhuma arte, pois é uma coisa espontânea; mas morrer bem é a arte das artes." Comenius - "A arte de morrer" - Organizador Franklin Santana, vol. 3,pág. 3

Barroco, Maria de Fatima Candido; Ferraz, Dayse M. de Melo Coelho; Oliveira, Maridite C. Gomes de; Oliveira, Marli Goulart T.; Muller, Walter. Humanização: Cuidado com a Finitude e o Morrer. In: Anais do Congresso Internacional de Humanidades \& Humanização em Saúde [= Blucher Medical Proceedings, num.2, vol.1]. São Paulo: Editora Blucher, 2014. ISSN 2357-7282

DOI 10.5151/medpro-cihhs-10628 